\title{
RUSSIAN FINANCIAL MARKETS IN JUNE-JULY 2015
}

\author{
E. Gorbatikov, E.Khudko
}

As in June, the MICEX Index in July was fluctuating near 1630 index points. However, it ended at the lowest in the period under review, down 3\% within the month. The Oil \& Gas Index fell and the oil \& gas industry lost near 1\% in the MICEX capitalization structure due to more than a $13 \%$ fall of oil prices. The Chemical and Petrochemical Index advanced higher than other industry indices. The MICEX daily average turnover declined for the third straight month.

The situation in the Russian domestic corporate bond market was relatively normal despite adverse external environment and negative internal trends in the economy. The key market indicators such as the corporate bond market volume and index, the weighted average yield rate of bond issuances; investors' activity remained high in the primary and secondary markets (particularly in the financial segment). Defaults on obligations to bondholders still remained a problem.

\section{The dynamics of basic structural indices in the Russian stock market}

At the beginning of the period under review, 26 June 2015 to 24 July 2015, the MICEX Index saw a downside trend and dropped by 8 July below $1600^{1}$ index points. The Index fully recovered during the following week and then began to sink on 16 July, reaching 1595.6 index points as of 24 July. The month-end decline was 3.0\%. Brent oil futures prices stood near $\$ 63$ per barrel during the last week of June 2015 and then began to decline earlier in July. The decline was speed up by the Iran Nuclear Deal 14 July. The crude oil price on 15 July dropped by $2.4 \%$. Late in the period under review crude oil was priced at $\$ 54.61$ per barrel. The last time the oil price hit even lower was March 2015. The oil price dropped by $13.4 \%$ at month's end.

Almost all of the blue chips kept falling in July. Gazprom, Rosneft and Norilsk Nickel showed a negative return within $4 \%$ and $6 \%$. VTB's shares lost a bit more, $7.8 \%$. Surgutneftegaz's preferred stock nominal quotations sank deep (almost 23\%) due to a dividend payout: most of the decline fell on 15 July, the first day after the dividend cut-off. LUKOIL was the only blue chip which ended positive $(2.8 \%)$ in the period under review.

For the third straight month VTB Bank remained the ROE leader ( $+78.06 \%$ a year) among highly liquid stocks. Surgutneftegaz $(+24.73 \%)$ gave way in the top3 to Norilsk Nickel (+28.21\%) and LUKOIL (+24.9\%). Rosneft's and Gazprom's annual ROE was near zero, whereas Sberbank remained negative at the year-end $(-6.27 \%)$.

The Telecommunications Index, which was the yield leader in the previous period under review,

1 The data hereinafter are MICEX closing data.

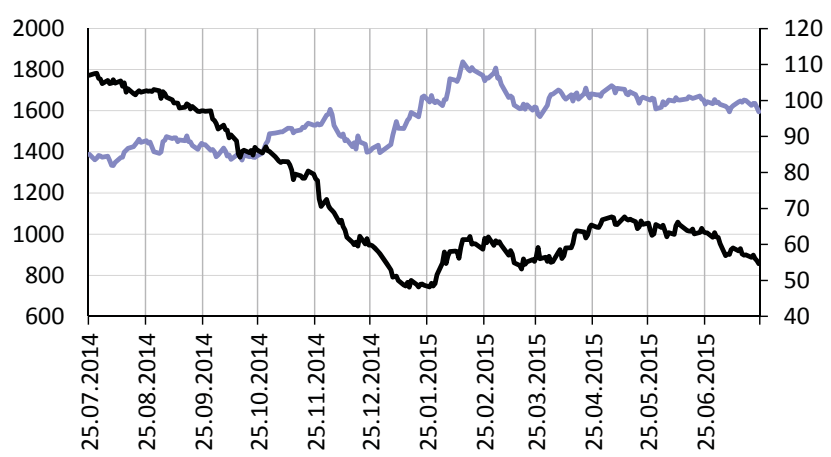

-The MICEX Index (left-hand scale)

—Brent crude oil prices, US\$ (right-hand scale)

Source: Quote RBC, Finam.

Fig. 1. The dynamics of the MICEX Index and futures prices of Brent crude oil in the period between 25 July 2014 and 24 July 2015

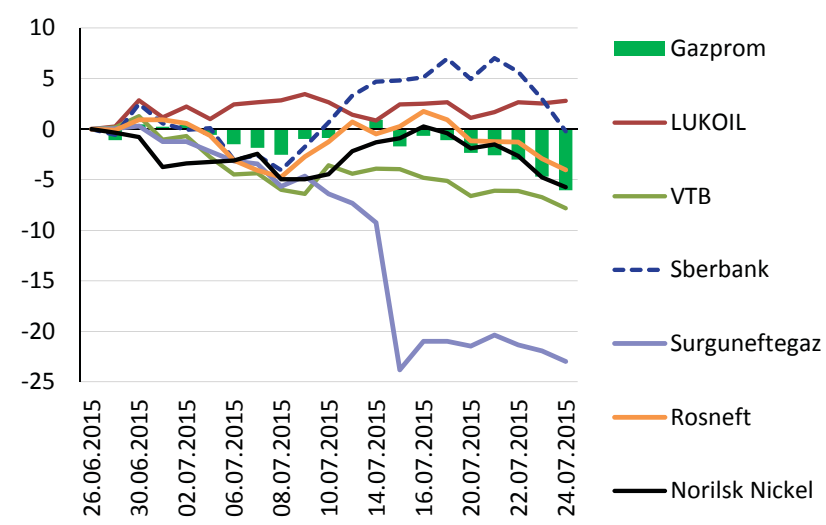

Source: Quote RBC, author's estimates.

Fig. 2. Growth rates in quotations of Russian highly liquid stocks in the Moscow Exchange in the period between 26 June 2015 and 24 July 2015 
sank deeper than other indices: MTS's shares (down more than 15\%) and Rostelecom's shares (down almost $10 \%)$ made the decisive contribution to the Index yield (-11.4\%). The Engineering Index kept falling, and the Oil \& Gas Index and the Energy Index saw an expectable decline (respectively by $3.6 \%$ and 4.4\%). The Chemical and Petrochemical Index took the lead in growth. Akron Chemical Company with more than a $17 \%$ growth contributed most to almost $10 \%$ growth of the Index. Additionally, the Transport Index and the Metal \& Mining Index saw a small positive dynamics.

The Moscow Exchange's (MOEX) turnover kept shrinking for the third straight month. The turnover in the period between 26 June 2015 and 14 July 2015 amounted to $\mathrm{Rb} 552.9 \mathrm{bn}$, being equal to $\mathrm{Rb} 26.3 \mathrm{bn}$ daily turnover, i.e. $13.4 \%$ below the value seen in the previous period under review, down $17.5 \%$ from the corresponding period of 2014 , and by more than $20 \%$ less than in Q2 2015.

The share of Sberbank in the MOEX total stock turnover increased $5 \%$ to $30.6 \%$ compared to the previous month. Gazprom was traditionally ranked $2^{\text {nd }}$ ( $11.9 \%$ of the MOEX total turnover), Surgutneftegaz was ranked $3^{\text {rd }}(7.7 \%$ of the total turnover). VTB, which was among the turnover leaders during the previous two months, was ranked only $70^{\text {th }}$ ( $4.4 \%$ of the total turnover). The top-3 turnover leaders accounted for $46.9 \%$ of the total MOEX turnover, whereas LUKOIL, Norilsk Nickel, Magnit, VTB, Rosneft accounted for another $30.2 \%$. Collectively, the top- 8 largest companies accounted for $77.1 \%$ of the turnover, up $0.6 \%$ from the previous month.

Russia-focused mutual funds continued to see investments outflow, which began in the previous period under review. According to the data of the Emerging Portfolio Fund Research (EPFR), the outflow in the period between 11 June 2015 and 15 July 2015

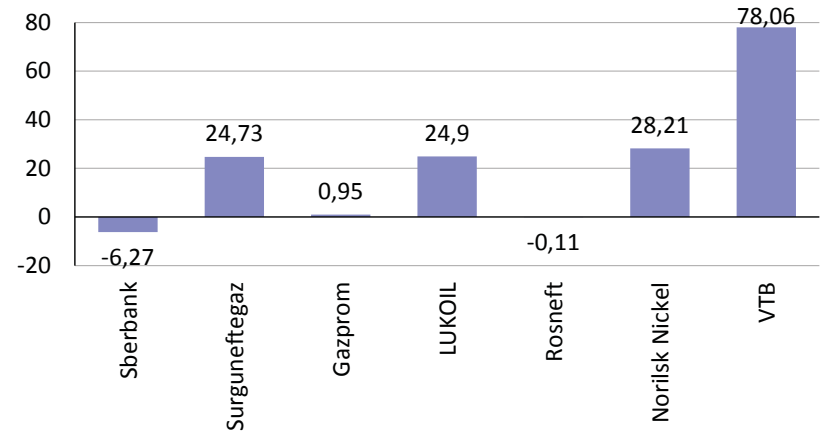

Source: Quote RBC, author's estimates.

Fig. 3. Growth rates in the value of highly liquid Russian stocks in the Moscow Exchange

in the period between 25 July 2014 and 24 July 2015

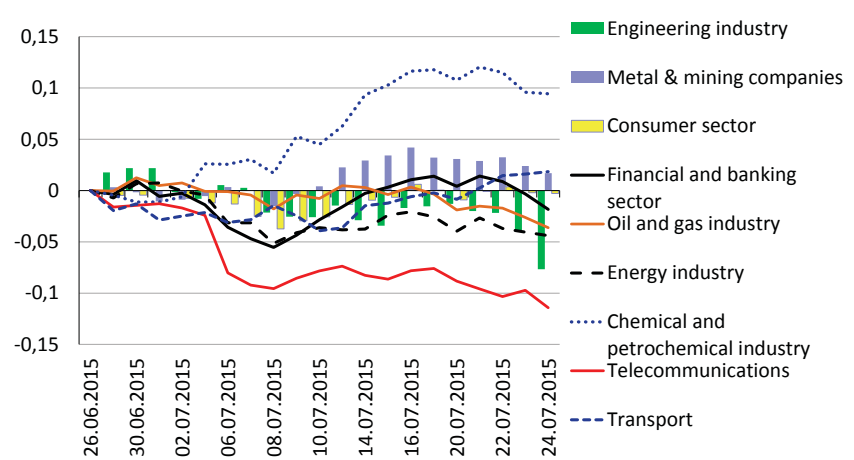

Source: Quote RBC, author's estimates.

Fig. 4. Growth rates in various sector stock indices in the Moscow Exchange in the period between 26 June 2015 and 24 July 2015

totaled $\$ 267.2 \mathrm{~m}$. The outflows as of 15 July continued for the eighth straight month. The year-to-month (earlier in July) aggregate inflows became negative.

The MICEX total capitalization as of 24 July 2015 amounted to $\mathrm{Rb} 26.88$ trillion ( $37.6 \%$ of GDP), $1.3 \%$ less than in the previous month. The structure of capitalization was changed basically due to a $0.92 \%$ shrink-

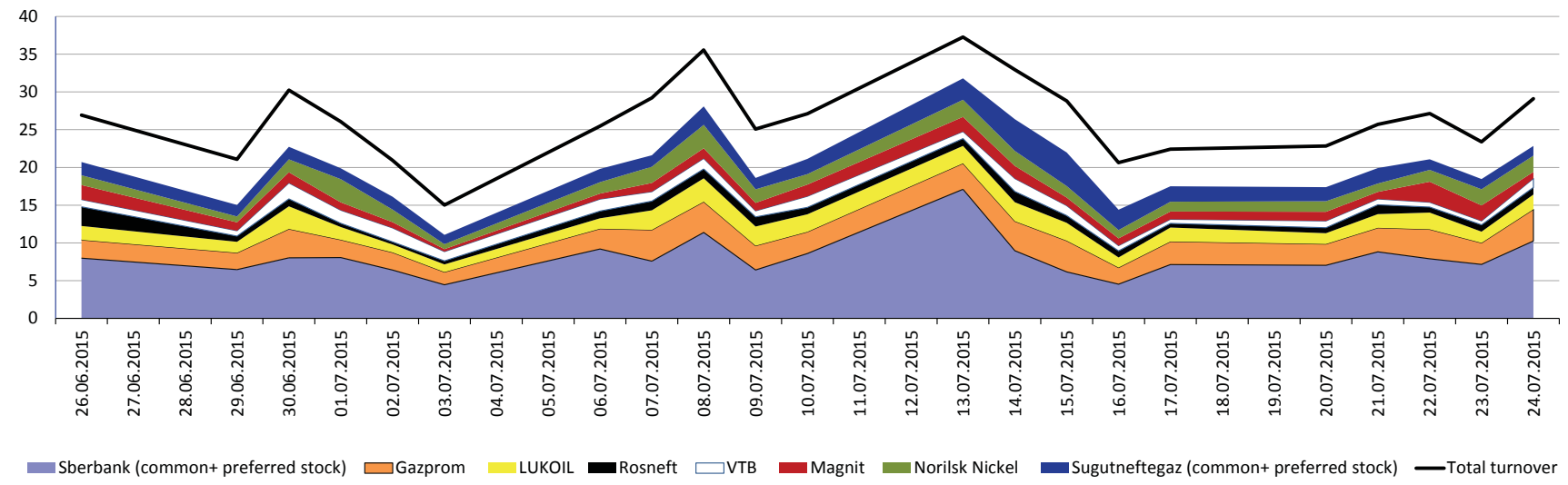

Source: RBK Quote, author's estimates.

Fig. 5. The structure of Moscow Exchange trading volumes in the period between 26 June 2015 and 24 July 2015 
age of the oil \& gas industry as oil prices dropped. The share of the metal and chemical industries increased $0.48 \%$ and $0.38 \%$ respectively, whereas other industries showed no significant changes. The oil \& gas industry as before accounted for a half of the capitalization (47.07\%), whereas the Metal \& Mining Industry (18.50\%) and the Financial sector (13.44\%) were ranked $2^{\text {nd }}$ and $3^{\text {rd }}$ respectively. Other industries accounted for a little more than $20 \%$ of the turnover.

\section{Corporate bond market}

The volume of Russia's domestic corporate bond market (measured by the par value of outstanding ruble-denominated securities including those issued by non-residents) in July 2015 kept growing at annual average rates. The volume by the end of July hit again the all-time highest, reaching $\mathrm{Rb} 7.576,4 \mathrm{bn}$, $2.1 \%$ above the value seen early in May $2015^{1}$. The past period saw substantial changes in the number of both outstanding bond issuances (1144 corporate bond issuances denominated in national currency were registered versus 1127 issuances registered as of the end of June) and issuers represented in the debt segment (374 issuers against 367 companies). Sixteen dollar-denominated bonds issuances of Russian companies (worth a total of more than \$2.2bn) and one JPY-denominated bond issuance remained outstanding after a foreign currency denominated debt was redeemed in July.

Investors' activity in the secondary corporate bond market in July increased a bit, but remained overall at the annual average level. For instance, the MOEX total trading volume was $\mathrm{Rb} 124.3 \mathrm{bn}$ in the period between 23 June 2015 and 22 July 2015 (by contrast, the trading volume was $\mathrm{Rb} 111 \mathrm{bn}$ in the period between 26 May 2015 and 22 June 2015). The number of transactions in the period under review increased more substantially to 26,900 (by contrast, 22,400 MOEX transactions were registered in the previous period) ${ }^{2}$.

The Russian Corporate Bond Market Index (IFXCbonds) in July kept growing at annual average rates. The Index increased 6.8 points by the end of the month (or $1.7 \%$ ) compared to the value seen at the previous month's end. The corporate bond average weighted yield decreased in the past period (from $12.87 \%$ late in June to $12.23 \%$ by the end of July 2015 ), but remained much higher than the central bank interest rate (Fig. 7) ${ }^{3}$. Despite a moderately positive dynamics of the bond yield rate, the corporate bond portfolio duration declined for the straight fourth month, remaining at its

1 According to the data provided by Rusbonds Information Agency.

2 According to the data provided by Finam Investment Company.

3 According to the data provided by Cbonds Information Agency.

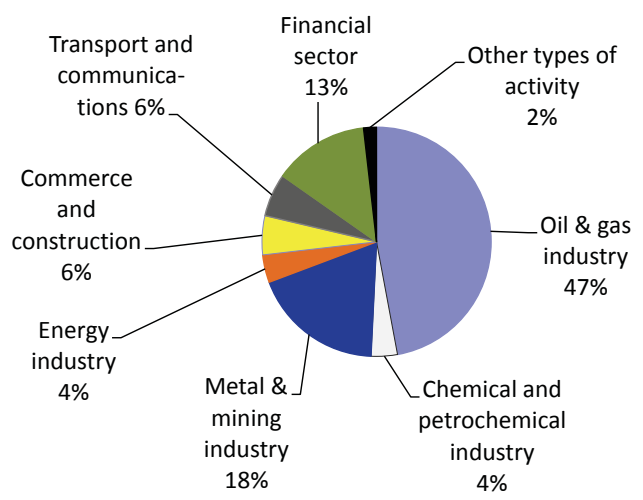

Source: The Moscow Exchange official website, the author's estimates.

Fig. 6. The structure of stock market capitalization by type of economic activity as of 24 July 2015

annual average level, - duration as of the end of July was 408 days, 22 days less that the value seen as of the end of June. Considering the declined bond yield rate, it implies a shorter average maturity of securities in the market.

Despite the overall decline in the bond yield rates, the most liquid segment of the corporate bond market saw mixed dynamics. Bond issuances of the following companies saw most of the decrease (by more than 1.5 p.p.): OAO Gazpromneft and OAO Otkritie Holding. OAO VTB Bank, JSC Gazprombank, OAO Moscow Unified Electric Grid Company saw their rate increase more than 1.5 p.p. The technology segment saw a moderate downside (by an average of 0.2 p.p.) for the straight second month. Most liquid securities of production and financial companies showed stabilization in the past period. The yield increased substantially in the energy segment (by an average of 0.4 p.p.) $)^{4}$. Securities of financial companies were in higher demand, in particular, Binbank bonds

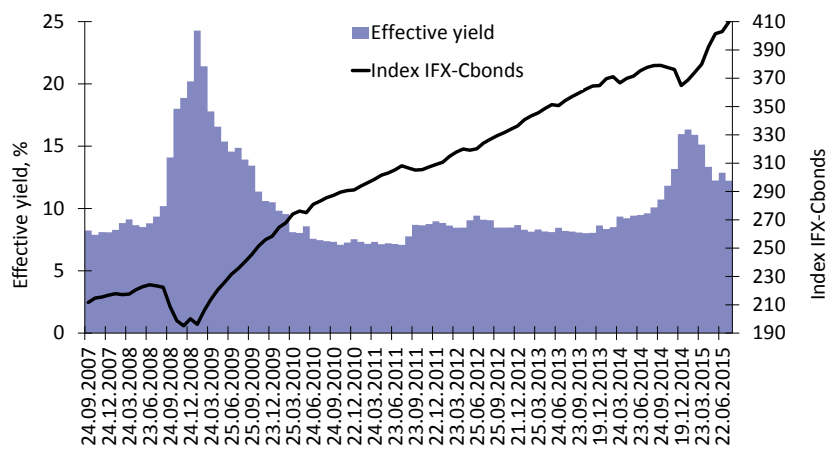

Source: According to the data provided by Cbonds Information Agency.

Fig. 7. The dynamics of the Russian corporate bond market index and average weighted yield

4 According to the data provided by Finam Investment Company. 
after the news came up that the issuer had acquired MDM Bank.

It should be noted that issuers' activity in seeking new fundraising increased in the period under review. For instance, five issuers registered 10 ruble-denominated bond issuances with an aggregate par value of $\mathrm{Rb} 71.3 \mathrm{bn}$ in the period between 23 June 2015 and 22 July 2015 (by contrast, 21 bond issuances with an aggregate par value of $\mathrm{Rb} 53.1 \mathrm{bn}$ were registered in the period between 26 May 2015 and 22 June 2015) ${ }^{1}$. A single large bond issuer, OAO Russian Agricultural Bank, accounted for the highest value of bond issuances, registering three of such issuances with an aggregate par value of $\mathrm{Rb} 30 \mathrm{bn}$. Large issuances also were registered by PJSC Bank Otkritie (a full-service financial corporation) and PJSC Federal Power Generating Com pany - RusHydro. However, this involves not only positive dynamics of quantitative indicators, but also some structural changes. For instance, the Russian market may for the first time in its history list bonds denominated in China's yuan: JSC Gazprombank registered four series of listed bonds with an aggregate par value of $2.85 \mathrm{bn}$ yuans (more than $\mathrm{Rb} 24 \mathrm{bn}$ at the exchange rate quoted as of the registration date). Additionally, OAO VEB-Leasing registered a single bond issuance with a par value of $\$ 200 \mathrm{~m}$.

At the same time, investors' activity increased in the primary market. For instance, 18 issuers placed 27 bond issuances with an aggregate par value of $\mathrm{Rb}$ 194.2bn in the period between 23 June 2015 and 22 July 2015 (by contrast, 30 issuers placed 42 bond issuances with an aggregate par value of $\mathrm{Rb} 158.6 \mathrm{bn}$ in the period between 26 May 2015 and 22 June 2015) (see Fig. 8). Large bond issuances were placed by OAO Russian Railways, OAO Atomic Energy Power Corporation (Atomenergoprom), State Corporation "Bank for Development and Foreign Economic Affairs (Vnesheconombank), Oil Transporting Joint-Stock Company Transneft ${ }^{2}$. Most of the bonds issued in the period under review were listed bonds. Many bond issuers managed to raise funds with quite a long maturity: Mortgage Agent Pulsar-1 issued bonds with a maturity of 30 years, while Russian Railways placed two bond issuances with a maturity of 25 and 20 years, Magistral Dvukh Stolits issued bonds with a maturity of 15 years, and another eight bond issuers raised funds with a maturity of 10 years.

1 According to the data provided by Rusbonds Information Agency.

2 According to the data provided by Rusbonds Information Agency.

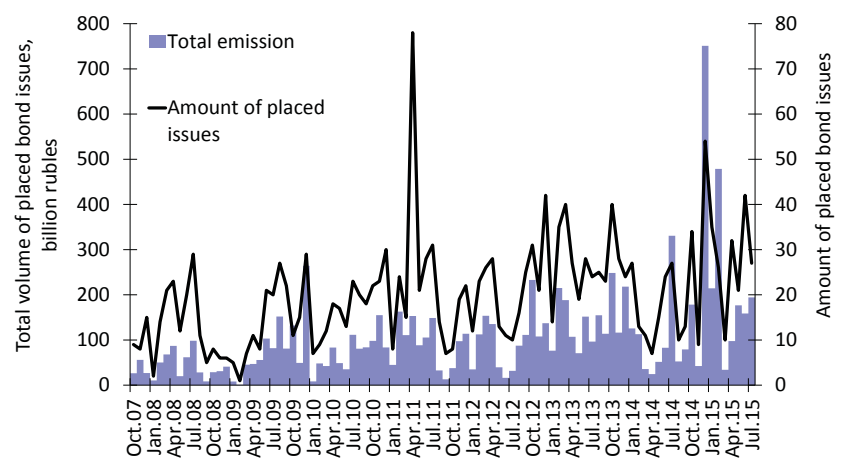

Source: According to the data provided by Rusbonds information agency.

Fig. 8. The dynamics of initial public offerings of corporate bonds denominated in the national currency

The Bank of Russia in July cancelled a record number of 32 corporate bond issuances on the grounds that not a single security was placed (two thirds of a bond series were declared void on the same grounds in the previous few months) ${ }^{3}$. It should be mentioned however that 26 of the cancelled bond issuances, which were registered more than a year ago and most of which were expected to be placed for qualified investors, were issued by VTB Capital Finance (a limited liability company). Obviously, this resulted because of the internal corporate policy rather than market trends.

In the period between 23 June 2015 and 22 July 2015 all of the 13 bond issuers redeemed their ruble-denominated debts with an aggregate par value of $\mathrm{Rb} 42 \mathrm{bn}$ and one foreign currency denominated debt with a par value of $\$ 153 \mathrm{~m}$. (in the previous same period a single issuer failed to honor its obligations at maturity and announced a technical default). Thirteen corporate bond issuances worth a total of $\mathrm{Rb} 59,7 \mathrm{bn}$ are due for maturity in August $2015^{4}$.

However, failures to meet obligations to bondholders was still a problem: Utair Finance (Limited Liability Company) declared actual default apart from a few technical defaults ${ }^{5}$, failing to redeem 13 bond issuances on put date. In addition, another issuer announced actual default on coupon yield payment (a few technical and actual defaults on coupon yield payment and redemption of the par value were announced in the previous same period) $)^{6}$.

3 According to the data provided by the Bank of Russia.

4 According to the data provided by Rusbonds Information Agency.

5 In other words, when a bond issuer is unable to repay to bondholders even during the grace period.

6 According to the data provided by Rusbonds Information Agency. 